\title{
Enhancement of Science Learning Outcomes Through Two Stay Two Stray Learning Model Assisted With Mind Mapping Media
}

\author{
Mugi Rahayu W \\ Primary School Teacher Education Study Program, FIP, Universitas Pendidikan Ganesha, Indonesia. \\ Email: mugirahayu1998@yahoo.com
}

I Komang Sudarma

Educational Technology Study Program, FIP, Universitas Pendidikan Ganesha, Indonesia Email: sudarmadede@gmail.com

I Ketut Dibia

Primary School Teacher Education Study Program, FIP, Universitas Pendidikan Ganesha, Indonesia Email: Ketutdibia31@gmail.com

\author{
A R T I C L E I N F O \\ Article history: \\ 1 Mei 2020 Received in \\ revised form \\ 11 Juni 2020 \\ Accepted 10 Juli 2020 \\ Available online 25 Agustus \\ 2020

Kata Kunci:
TSTS, mind mapping,
hasil belajar \\ Keywords: \\ TSTS, Mind Mapping, \\ Learning Outcomes
}

\begin{abstract}
A B S T R A K
Dilaksanakannya penelitian ini berdasarkan atas pemasalahan-permasalahan yang ditemukan pada saat observasi, yaitu sulitnya siswa belajar khususnya dalam pembelajaran IPA yang berdampak terhadap hasil belajar siswa dan pembelajaran yang masih bersifat teacher centered yang menyebabkan siswa menjadi pasif. berdasarkan permasalahan tersebut, maka penelitian ini bertujuan untuk menganalisis efektivitas model Two Stay Two Stray berbantuan mind mapping terhadap hasil belajar IPA siswa. Jenis penelitian ini ialah eksperimen semu dengan desain Nonequivalent Control Group Design. Rancangan penelitisn yang digunakan yaitu post-test only control group design. Populasi pada penelitian ini berjumlah 147 siswa yang terdiri atas empat kelas. Penentuan sampel dilakukan dengan cara random sampling berupa pengundian. Jumlah sampel sebanyak 72 siswa, yaitu kelas eksperimen berjumlah 36 siswa dan kelas kontrol berjumlah 36 siswa. Pengumpulan data post-test dilakukan dengan metode tes yang berjenis objektif pilihan ganda. Kemudian, dilakukan analisis dengan rumus uji-t. Dari hasil analisis, ditunjukkan bahwa didapatkan $t_{\text {hitung }}=3,920>t_{\text {tabel }}=1,99444$. Berdasarkan hasil tersebut, terdapat perbedaan hasil belajar IPA yang signifikan antara kelas yang diberikan perlakuan model pembelajaran TSTS berbantuan metode mind mapping dengan kelas yang diberikan perlakuan model pembelajaran konvensional. Hasil dari perhitungan didapat kelas eksperimen memiliki mean yang lebih tinggi daripada kelas kontrol, yaitu
\end{abstract} 79,06>68,75. Berdasarkan hal tersebut, maka model pembelajaran TSTS berbantuan metode mind mapping efektif terhadap hasil belajar IPA siswa.

\begin{abstract}
A B S T R A C T
The implementation of this research is based on the problems found at the time of observation, namely the difficulty of students learning, especially in science learning that has an impact on student learning outcomes and learning that is still teacher-centered that causes students to be passive. Based on these problems, this study aims to improve the learning outcomes of science students in grade $\mathrm{V}$ elementary school. This type of research is a quasi-experimental design with Nonequivalent Control Group Design. The research design used is the post-test only control group design. The population in this study amounted to 147 students consisting of four classes. The determination of the sample is done by random sampling in the form of a draw. The number of samples was 72 students, namely the experimental class totaling 36 students and the control class totaling 36 students. The students' natural science post-test data collection is done by using multiple-choice objective test methods. Then, the t-test formula was analyzed. From the results of the analysis, it was shown that $\mathrm{t}$-count $=3,920$ was obtained and compared with t-table at the $5 \%$ significance level and $\mathrm{dk}=36+36-2=70$ so that the price of t-table $=1.99444$ was obtained. Based on these results, there are significant differences in science learning outcomes between the classes given the treatment of the TSTS learning model aided by the mind mapping method and the classes given the treatment of conventional learning models. The results of the calculations obtained the experimental class has a higher mean than the control class, which is $79.06>68.75$. Based on this, the TSTS learning model is assisted by an effective mind mapping method to the science learning outcomes of fifth-grade students of elementary school.
\end{abstract}

\section{Introduction}

Learning is an activity that educators do to their students reciprocally so that the process of acquiring knowledge, forming attitudes and trust in their students can occur (Dimyati \& Mudjiono, 1999; Gading et al., 2018; Huda, 2014). Each level of education has different learning activities. These differences depend on the 
learning needs and characteristics of students. Given that elementary school children still have characteristics at the concrete operational stage, it makes it easier for elementary school children to understand learning if students experience it directly and real. In general, elementary students enjoy feeling or doing something directly and enjoy playing (Bujuri, 2019; Khaulani et al., 2020). The success of the implementation of learning is influenced by the ability of teachers to understand the characteristics of their students. Based on the characteristics of the developmental stages of elementary students, elementary school student learning activities should be structured in such a way as to improve student learning outcomes.

Learning outcomes are changes in behavior that include cognitive, affective, and psychomotor aspects that are owned by students after getting a learning experience which is expressed in the form of symbols, numbers, letters, and sentences. (Gading et al., 2018; Puspitasari, 2019). The high level of student learning outcomes will indicate the level of students' ability to understand learning material. To improve student learning outcomes, the role of the teacher is needed in designing the learning process. A good learning process should be able to involve students directly to build their knowledge so that students will gain a deep understanding and can improve student learning outcomes. The teacher as a facilitator who supports the activeness of students in building their knowledge can design, implement, and evaluate learning programs that can develop student learning competencies from a variety of learning contents. Various learning content is taught by teachers at school, one of which is Natural Sciences (IPA).

Science is one of the contents that is integrated and studied in all levels of education on an ongoing basis. Science is a collection of knowledge of natural phenomena that occur and are systematic in nature. Science has 3 components, namely as a product, process, and scientific attitude. Science as a product, what is meant in this case is facts, principles, theories, and laws. Science as a process, what is meant in this case is the procedure for solving problems with the scientific method from composing hypotheses to making conclusions. Science as a scientific attitude, what is meant in this case is a scientific attitude that includes a sense of curiosity about natural phenomena, objects, living things, and cause and effect relationships that can cause new problems and can be solved with the right steps (Dewi \& Negara, 2020; Suja, 2014). Science learning cannot be learned passively or just listen to the teacher in explaining the concept of learning in the absence of experiments, observations, and experiments actively to improve the experience and activeness of students directly (Handayani, 2018; Juniantari, 2019).

The purpose and role of science content are very large, namely to provide children with the knowledge to get to know the world they live in, provide practical knowledge, instill scientific attitudes to be applied in their daily lives, educate children to appreciate the services of science inventors who have conducted research. beforehand, as well as providing knowledge, concepts, and science skills that will be used in continuing education to a higher level (Ernawati, 2017; Wote, 2020). Through science education, it is hoped that students will be able to develop logical, rational, analytical, and critical thinking skills in supporting the development of science and technology. Based on this, in the learning process in elementary schools, teachers are expected to use innovative learning models and various methods, so that students become more creative and active and can work together, be responsible, help each other in solving learning problems so that the goals learning can be achieved optimally.

The learning process that occurs in elementary schools in learning science students tends to memorize concepts, learn science as a product, theory, and law. Besides, teachers are also less creative in building student knowledge independently. Many teachers still use teacher-centered learning, so that there is no effect on student learning outcomes in the future (Juniantari, 2019; Kusumayanti, 2013). According to (Hendrawan, 2017), not optimal learning outcomes occur because in the learning process the teacher applies the lecture method which causes one-way interaction. One-way interaction causes the learning process to tend to be passive, less creative, and less meaningful. One-way learning also causes a lack of interaction between students. Besides, the lack of teacher knowledge and the implementation of innovative learning models and learning methods causes learning to seem monotonous, causing students to become bored quickly, less active, saturated, and less confident. Various problems in the learning process greatly affect student learning outcomes.

Similar problems were also found in SDN 1 Dajan Peken, to be precise, grade V in science learning. Based on observations and interviews with one of the class V teachers held on Monday, October 21, 2019, it shows that there is still a need for improvement in science learning. The problems found included (1) in teaching, the learning model used by the teacher was still monotonous, namely conventional, so that it seemed less attractive (2) learning was still teacher-centered so that students seemed passive; (3) the notes given by the teacher are still in the form of a long text which makes students lazy to read them again; (4) students are less creative in making notes with their creations, and (5) students experience difficulties in learning science. In addition, it was also found that the results of PTS I on the science content of grade V SD Negeri 1 Dajan Peken students were still under KKM. More detail can be seen in the following table. 
Table 1. Results of PTS IPA Class V SDN 1 Dajan Peken Students

\begin{tabular}{|c|c|c|c|c|c|c|}
\hline \multirow{2}{*}{ Class } & \multirow{2}{*}{$\begin{array}{c}\text { Total } \\
\text { Students }\end{array}$} & \multirow{2}{*}{ KKM } & \multicolumn{4}{|c|}{ Jumlah Siswa } \\
\hline & & & Completed & Percentage & Incompleted & Percentage \\
\hline V A & 36 & 70 & 18 & $50 \%$ & 18 & $50 \%$ \\
\hline V B & 36 & 70 & 19 & $52,8 \%$ & 17 & $47,2 \%$ \\
\hline $\mathrm{VC}$ & 37 & 70 & 17 & $45,9 \%$ & 20 & $54,1 \%$ \\
\hline V D & 38 & 70 & 20 & $52,6 \%$ & 18 & $47,4 \%$ \\
\hline & Total & & 75 & $50,3 \%$ & 72 & $49,7 \%$ \\
\hline
\end{tabular}

(Source: Mark Archives of PTS IPA Class V SDN 1 Dajan Peken Students in 2019)

The table above shows that the average value of the Middle Semester I grade V SDN 1 Dajan Peken assessment on the IPA content. It can be seen that there are still many students whose scores have not reached the specified minimum completeness criteria (KKM), which is 70 . This can be seen from a total of 147 students, only $50.3 \%$ whose scores reached the KKM or the equivalent of 75 students. While the remaining $49.7 \%$ or equivalent to 72 students whose scores are still below the KKM. The comparison between students whose scores are incomplete and those who have not completed is very thin because these scores reflect student learning outcomes themselves. This shows that it is necessary to make efforts to improve student learning outcomes and minimize students whose grades are still below the KKM. The existence of these problems, because the learning used is still conventional and teachers are less creative in applying innovative models in the classroom learning so that the class seems less conducive. In fact, as a teacher, he should be able to adjust, select, and apply a learning model that is in accordance with the material being taught to be able to vary learning to keep it interesting. This was supported by Sudjana (N. Handayani, 2018) which explains that one of the causes of learning outcomes cannot be achieved properly due to the tendency of students to be passive in learning. To actively attract students' role in learning, teachers should use models in the implementation of learning. With the use of a learning model, it can lead to more effective learning. Likewise in this problem, an effort is needed to improve students' understanding and mastery of science material which greatly influences student learning outcomes. To address this, of course, a solution is needed. The solution that can be done is the application of a cooperative learning model with a system of solving problems in groups through small discussions. The cooperative learning model is one model that can increase student activity, the interaction between students, cooperation between students to be active in learning so that every student is responsible for doing their best. The characteristic that stands out in cooperative learning is heterogeneity. In cooperative learning, students learn together in small groups consisting of 4-6 heterogeneous people (Hendra et al., 2017).

One of the cooperative learning models is the Two Stay Two Stray learning model. The TSTS learning model is a learning system in groups that aims so that students can work together well, be responsible, help each other solve problems, and motivate one another (Astuti, 2016; Huda, 2014). The TSTS application system is that the number of students in each group is four people who have different tasks. Two people must provide information to those who visit and two people have the task of visiting other groups to get information. With the TSTS model, it can train students' courage to express their thoughts and opinions because in learning there is a process of conveying information to other group members. In this TSTS learning model, students are invited to work together in finding a learning concept. The use of the TSTS model leads students to be active, both in discussing, questioning, searching for answers, explaining, and listening to material explained by other friends (Astuti, 2016; Hajar \& Surya, 2018; Handayani, 2018). The more active students are in the learning process, the more learning experiences will be achieved. The advantages of the Two Stay Two Stray type of cooperative learning model are that it provides an opportunity for each group to be able to share information with other groups about the things they discuss, improve student learning outcomes, avoid boredom due to permanent group formation, and train students' ability to share information. to friends inside or outside their group (Fitrianingrum, 2018; Hajar \& Surya, 2018).

A learning model will be more effective if it is applied using the right media. Likewise, the TSTS learning model will be more effective if it is supported by the right learning media. The role of the media is very important in learning, one of which is a way for learning to take place in a fun way. Learning media that are suitable for application to science content with the TSTS model are mind mapping media. Mind mapping media is a creative way for every learner to generate ideas. The purpose of mind mapping is to create a patterned subject matter that can record or recall information (Apriliana et al., 2019; Juniantari, 2019). With a combination of colors, writing, shapes, and others, it can help the brain to absorb information so that students can remember the material described by the teacher longer. Especially the science content, the dense material makes students quickly bored and lazy to learn it. In addition, some of the advantages of mind mapping are (1) being able to express opinions freely, (2) being able to collaborate with friends, (3) notes more compact, clear, and neat, (4) easier to find notes when needed, 
(5) ) notes focused on the core of the material, (6) easy to see the overall picture, (7) helps the brain to organize, remember, compare, and make connections between materials, (8) makes it easier to add new information, (9) fast in reviewing, (10) is unique so it doesn't make you bored when studying (Latifah, 2020; Rusmayanthi, 2016).

Based on the advantages of the TSTS and mind mapping models, a collaborative model for both models and methods was designed to make students more active and able to collaborate, so that student learning becomes more meaningful and student learning outcomes increase. With this collaboration, it is hoped that problems related to learning outcomes can be overcome. Where the TSTS learning model assisted by the mind mapping method is very suitable if applied in elementary schools because it can build students' enthusiasm in learning and students can understand the subject matter obtained. The TSTS learning model assisted by the mind mapping method is very suitable if applied in elementary schools because it can build students' enthusiasm for learning and students can understand the subject matter that is obtained. The TSTS learning model assisted by the mind mapping method in science content has a positive impact on students whose learning outcomes are still low, because the application of the TSTS learning model students is required to be able to work with groups that make students more active and can exchange answers and share knowledge. so that there is a discussion process in the group. The implementation of the TSTS learning model assisted by the mind mapping method of students is expected to increase the sense of cooperation, responsibility, and be able to play an active role in learning activities that influence student learning outcomes.

This problem solving is supported by research (Rusmayanthi, 2016) which resulted in a significant difference in results between learning activities and science learning outcomes in classes given the mind mappingassisted TSTS model treatment with the class that applied direct learning model treatment. Research conducted by (Rosmalah, 2017) which resulted that the cooperative learning model type two stay two strays can improve social studies learning outcomes in grade IV SD Negeri 216 Talungeng, Barebbo District, Bone Regency. Research conducted by (Bilqis, 2018) which results that classes taught using the two stay two stray learning models, has higher learning outcomes than classes taught using the Card Sort learning model. Then the research conducted by (Hardika, 2018) which shows an increase in student learning outcomes after the application of the two stay two stray learning model in social studies subject matter cooperatives. And research conducted by (Apriliana et al., 2019) which results that the scientific literacy of students who learn with Mind Mapping assisted Guided Inquiry learning is higher than conventional learning. Based on the relevant research results, it can be concluded that the two stay two stray models assisted by the mind mapping method can improve student learning outcomes.

Based on the explanation about the advantages of the TSTS mind mapping model, a research objective was formulated, namely to analyze the effectiveness of the two stay two stray learning model assisted by the mind mapping method on science learning outcomes in fifth-grade students of public elementary school 1 Dajan Peken, Tabanan District, 2019/2020 academic year. The number of studies that have been carried out using the two stay two stray learning models assisted by the mind mapping method, so the novelty of this research is compared to existing research which lies in the subject matter. Science content on theme 7 (Events in Life) has never been taught using the two stay two stray learning model assisted by mind mapping by other researchers. The steps in this model are in accordance with the opinion of Lee, 2002 (Hendrawan, 2017b) as follows: (1) students work together in groups of four as they can; (2) after completion, two people from each group will leave the group and each group will leave the group and each visit the other group; (3) two students who live in the group are tasked with sharing their work and information with their guests; (4) guests excuse themselves and return to their group and report their findings from other groups; (5) groups match and discuss the results of their work. These steps combine with mind mapping media.

\section{Method}

This type of research is quantitative research with the research unit in the form of classes so that what is used is quasi-experimental research. The research design used was Post-test Control Group Design. This study has two variables, namely the independent variable is the TSTS learning model assisted by the mind mapping method and the dependent variable is the science learning outcome. The two classes were given different treatments. Furthermore, at the end of learning between the experimental and control classes, a post-test was given with the same questions related to the material that had been given during the study. The stages carried out in this study consisted of the preparatory stage, namely designing a lesson plan based on the learning steps of the TSTS learning model assisted by the mind mapping method, the implementation stage, namely during the implementation of the model until the post-test administration, and the final stage, namely analyzing the science learning outcome data. students.

This research was conducted at SDN 1 Dajan Peken, Tabanan District, Academic Year 2019/2020. Population according to Sugiyono (Zairmi et al., 2019) is an area of generalization determined by the researcher to study which consists of objects or subjects that have certain characteristics. In this study, the population used 
was all class V SDN 1 Dajan Peken registered in 2019/2020 with a total population of 147 students (four parallel classes). From a population of four classes, the research sample was determined by doing a random sampling technique, in this case, the class was random. The samples obtained after the draw were the VA class as the experimental class, totaling 36 students, and the VB class as the control class, totaling 36 students.

The data collected in this study were in the form of science competency knowledge of class $\mathrm{V}$ students. The data were collected using the test method. The variables that are determined to be researched serve as benchmarks in the preparation of the test. From the operational definition of the variable, it is then developed to determine the indicators that are measured. Indicators that have been determined, described, and developed into various questions. However, before making question items, first, a grid of instruments was made to measure students' cognitive science domains and to facilitate the preparation of instruments. The following is the grid of the instruments used.

Table 2. Science Class V Themes Blueprint

\begin{tabular}{|c|c|c|}
\hline Basic competencies & Indicators of Questions & $\begin{array}{l}\text { Cognitive } \\
\text { Realm }\end{array}$ \\
\hline \multirow{9}{*}{$\begin{array}{l}\text { 3.7 Analyzing the effect of heat on } \\
\text { changes in temperature and shape } \\
\text { in daily life }\end{array}$} & 3.7.1 Analyzing the various forms thing. & $\mathrm{C} 4$ \\
\hline & $\begin{array}{l}\text { 3.7.2 Choose objects that include objects solid, } \\
\text { liquid, and gas based on the characteristics } \\
\text { characteristics. }\end{array}$ & $\mathrm{C} 5$ \\
\hline & 3.7.3 Analyzing how to change form solid object. & $\mathrm{C} 4$ \\
\hline & 3.7.4 Find examples of solid objects liquid, and gas. & $\mathrm{C} 4$ \\
\hline & 3.7.5 Examine the causes changes in form. & $\mathrm{C} 5$ \\
\hline & $\begin{array}{l}\text { 3.7.6 Summarize the meaning of events freeze, melt, } \\
\text { evaporate, condense, and sublimate. }\end{array}$ & $\mathrm{C} 4$ \\
\hline & $\begin{array}{l}\text { 3.7.7 Examine the causes of events freeze, thaw, } \\
\text { evaporate, and condense. }\end{array}$ & $\mathrm{C} 4$ \\
\hline & $\begin{array}{l}\text { 3.7.8 Analyze an example of a frozen event, melts, } \\
\text { evaporates, condenses, and sublimate in } \\
\text { everyday life. }\end{array}$ & $\mathrm{C} 4$ \\
\hline & 3.7.9 Analyze a way of knowing a objects have heat. & $\mathrm{C} 4$ \\
\hline
\end{tabular}

The instrument above was developed into a multiple-choice objective test of 35 items with four answer choices on each item. The test that was arranged as a test related to students mastery of the fifth-grade science material that had been taught at the time of the research. Students who answered the items correctly got a score of 1 and students who answered incorrectly got a score of zero. Then the overall score is added up to get a score or results of the competence of student knowledge. The test is said to be good, if it has characteristics, namely the validity test, reliability test, difference power test, difficulty level test, and has a good quality of imposter too. Because in the test questions, there are invalid items that indicate that these items are not good enough so they are not used in the post-test. This led to the use of only 30 test items in the IPA post-test data collection. The data analysis technique used is statistical analysis. Descriptive analysis to calculate the mean, median, mode, variance, and standard deviation. Meanwhile, inferential analysis is used in testing the research hypothesis. However, before testing the hypothesis, testing the normality and homogeneity of the variance is done first. Testing the normality of this study using the Chi-Square with a significant level of 5\% and $\mathrm{dk}=\mathrm{k}-1$. In the test, there are two criteria, namely if the price of X2-count \&1t; X2-table, then the data is spread out normally distributed, which indicates that $\mathrm{H} 0$ is accepted and $\mathrm{Ha}$ is rejected. However, if the value of X2-count $\geq \mathrm{X} 2$-table shows the data is not normally distributed, which indicates that $\mathrm{HO}$ is rejected and $\mathrm{Ha}$ is accepted. If the data is normally distributed, then the variance homogeneity test is then carried out. In homogeneity testing, performed using Fisher\&\#39;s exact test at the 5\% significance level and the $\mathrm{dk}$ for the numerator is $\mathrm{n} 1-1$ and the $\mathrm{dk}$ for the denominator is $\mathrm{n} 2-1$. Criteria in the homogeneity test of variance, namely if F-count $\geq$ F-table, it indicates that the sample is not homogeneous. Meanwhile, if F-count $\leq$ F-table, it indicates that the sample is homogeneous. Hypothesis testing is carried out when the normality test and variance homogeneity test have been carried out. In this study, the hypothesis tested was H0: the learning outcomes of class V SDN 1 Dajan Peken Subdistrict for the 2019/2020 academic year in science learning applying the TSTS learning model assisted by the mind mapping method were the same or smaller than applying the conventional learning model. In the hypothesis test, the data analysis technique used is the t-test with the polled variance formula. 


\section{Result and Discussion}

The implementation of learning in the classroom during the research process runs smoothly in accordance with the RPP of the TSTS learning model assisted by the mind mapping method. Meetings in research have been held 6 times in the experimental class and also 6 times in the control class. At the end of the study, the two-class groups carried out a post-test with the same questions regarding the material that had been taught. After giving different treatments, data from the research results can be obtained and analyzed descriptively and inferentially. The descriptive test result data is presented in the following table.

Table 3. Descriptive Test Result Data

\begin{tabular}{lcc}
\hline \multirow{2}{*}{ Analysis } & \multicolumn{2}{c}{ Result of Post-test Data } \\
\cline { 2 - 3 } & Experiment Group & Control Group \\
\hline Amount of Data (n) & 36 & 36 \\
Minimum Score & 56,7 & 40 \\
Maximum Score & 100 & 93,3 \\
Mean & 79,06 & 68,75 \\
Median & 79,4 & 68,3 \\
Modus & 87,4 & 62,9 \\
\hline
\end{tabular}

Based on the results of the analysis presented in table 2, it was found that the post-test average score of the experimental group was higher than the post-test score of the control group. Therefore, it can be concluded that there is an increase in student science learning outcomes when using the TSTS learning model assisted by the mind mapping method. Furthermore, the prerequisite test is carried out, namely the normality test, homogeneity test, and hypothesis testing. The results of the normality test can be presented in the following table.

Table 4. Normality Test and Homogeneity Test

\begin{tabular}{lcccl}
\hline Normality Test & & & & \\
\hline Group & Significant Level & $\mathbf{X}^{\mathbf{2}}$-count & $\mathbf{X}^{\mathbf{2}}$-table & Decision \\
\hline Experiment & 0,05 & 6,6993 & 7,815 & Normal \\
Control & 0,05 & 4,1748 & 7,815 & Normal \\
\hline Homogeneity Test & & & & \\
\hline Homogeneous & $\mathbf{F}$ & -count & & Simpulan \\
Terms & & F-table & & \\
& & & & \\
\hline $\mathrm{F}_{\text {-count }}<\mathrm{F}_{\text {-table }}$ & 1,20 & 1,69 & Homogenous \\
\hline
\end{tabular}

Based on table 4, it is concluded that the post-test result data of the experimental group and the control group are normally distributed. The homogeneity test shows that the value of F-count $=1.20$. This value was compared with the F-table price of 1.69 at the 5\% significance level. This shows that F-count <F-table, it can be concluded that the post-test data of class V students' science learning outcomes between the experimental and control classes has a homogeneous variant.After the prerequisite test has been carried out and it has met the criteria, then the hypothesis is tested using the t-test formula (polled variance), the results of which are presented in the following table.

Table 6. Hypothesis Test

\begin{tabular}{cccccccc}
\hline No & Sample & N & dk & Mean & t-count & t-table & Information \\
\hline 1 & Class VA SDN 1 Dajan Peken & 36 & \multirow{2}{*}{70} & 79,06 & \multirow{2}{*}{3,20} & \multirow{2}{*}{1,99346} & $\mathrm{H}_{0}$ rejected \\
2 & Class VB SDN 1 Dajan Peken & 36 & & 68,75 & & & $\mathrm{H}_{\mathrm{a}}$ accepted \\
\hline
\end{tabular}

From the t-test analysis, the results obtained t-count $=3.20$. With a significance level of $5 \%$ and $\mathrm{dk}=70$, then the price of $\mathrm{t}$-table $=1.99346(\mathrm{t}$-count $=3.20 \& \mathrm{gt}$; $\mathrm{t}$ table $=1.99346)$. This shows that H0 is rejected. This shows that the TSTS learning model assisted by the mind mapping method is effectively used to improve science learning outcomes compared to groups of students who are taught with conventional learning models in fifth-grade students of SD Negeri 1 Dajan Peken, Tabanan District, Academic Year 2019/2020.Based on the results of the 
analysis using the t-test formula (polled variance) and obtained t-count $=3,920$. Then, the price of $t$ count is compared with the price of t-table with $\mathrm{dk}=70$ at a significance level of 5\% (0.05), obtained t table $=1.99444$. Because t-count $(3,920) \mathrm{t}$-table $=1.99444$ then $\mathrm{H} 0$ is rejected and $\mathrm{Ha}$ is accepted. This shows that it means that the learning outcomes of grade V students at Public Elementary School 1 Dajan Peken, Tabanan District, 2019/2020 Academic Year in science learning using the two stay two stray learning model assisted by the mind mapping method are greater than using conventional learning models on the theme of Events in Life. The calculation of the analysis obtained data results showing that the average score of students who were taught using the two stay two stray learning model assisted by the mind mapping method (79.06) and those taught using the conventional learning model (68.75) had a difference of 10,31. Thus there is a significant difference between the science learning outcomes of class V SD Negeri 1 Dajan Peken students who take part in learning using the two stay two stray learning model assisted by the mind mapping method with groups of students who are taught with conventional learning models on the theme of Events in Life. Several things were found in research, namely, students getting special experiences, developing cooperation skills, and interaction between students because through these interactions students are directly involved in learning so that students can explore their knowledge and can improve learning outcomes. This concurs with the statement from (Suyanti, 2017) which states that interaction between students can improve learning outcomes. With good interaction between learning components, it will make it easier for Sissa to receive learning material.

In the preparatory stage, the formation of heterogeneous groups of student learning with each group consisting of 4 people. Through group learning, students' ability to interact can develop. It is known together that the formation of small groups is a heterogeneous syntax of cooperative learning models. One of the cooperative learning models is the TSTS learning model. Huda (Arthaningsih, 2018) explained that the purpose of the heterogeneous group arrangement is to allow students to mutually teach and discuss with their friends. Through these discussions, the interaction will arise between students to exchange information with each other (Isjoni, 2016). This can support student learning success and is more effective than just teaching given by the teacher. Based on this, student learning outcomes can increase due to these interactions.

At the teacher's presentation stage, before entering the material, the teacher gives an apperception to provoke students with several questions and link them to the material to be studied. The giving of this apperception greatly affects the readiness of students in receiving the next material. Apperception that is right can deliver students in a sustainable pattern of thinking. In line with the opinion expressed by Mansur (2015) that apperception is very important because it is a stimulus to attract students' attention and makes learning more effective so that students understand the material being taught easier. Trianto (Safitri, 2020) argued that the material presented in science content is related to everyday life, it will be easier to learn and understand if the teacher first gives apperception.

The collaboration of these models and methods has a positive impact on learning outcomes due to the advantages of these models and methods. The advantages of the two stay two stray assisted mind mapping learning model that have been carried out in this study, namely by applying the two stay two stray model assisted by mind mapping students are more able to develop the ability to work with other students and provide special experiences because students are directly involved in learning so that they can explore their knowledge. In general, elementary students enjoy feeling or doing something directly and enjoy playing (Khaulani et al., 2020).

By using the TSTS model students become more active, able to work with teams, and learn responsibly with the tasks they get in their study groups. Good cooperation produces good results too. Likewise, in this case, cooperation between students can foster students' enthusiasm for learning so that learning becomes fun. Students are very enthusiastic about learning and students also find it easier to understand the material being taught.

In addition, another advantage of the application of the two stay two stray learning model assisted by mind mapping that has been carried out is the mind mapping method that can present images with attractive shapes and use bright colors. Elementary school-age students are not yet able to face abstract things but can understand mathematical symbols (Alvin, 2015). (Hidayat et al., 2020) also explained that the application of this model is more emphasized on combining colors and shapes so that it looks attractive. The use of images with interesting shapes in mind mapping can increase student motivation so that students can more easily understand the images presented. The images used in mind mapping can help students' brains to organize, remember, compare, and make connections between materials. This statement is in accordance with the opinion (Muhamad Husni, 2018; Pratama \& Yuniar, 2017; Suruni, 2018) that is, the combination of shapes and colors helps the brain to absorb information. Mind mapping can be designed according to the material needs that must be taught to students. With a variety of designs, the brain will find it easier to absorb information, and students' willingness to accept the material will be better.

With the application of the two stay two stray learning model assisted by mind mapping, students are more able to develop their collaboration skills with the team. This collaboration is one of the characteristics of the implementation of the two stay two stray learning model assisted by the mind mapping method. Through good 
cooperation, work can be completed faster, in this case, namely making a mind mapping of the material obtained. This collaboration makes each individual have their respective responsibilities. The learning process can run effectively because students can work together with their groups both in discussion and in the distribution of tasks so that the application of this model becomes very enjoyable. This concurs with Fatmawati (N. Handayani, 2018) which states that applying the two stay two stray learning models can provide students to create creativity in communicating related to the material so that learning becomes meaningful. Based on these findings, it can be stated that through group formation, students can study together with their friends and can develop interaction between students through small discussions within the group. The development of students 'ability to interact, the knowledge possessed by each individual is also developing, even the students' insights have increased towards the learning material. This has a positive impact on student learning outcomes. In addition, apperception is also said to be a benchmark in improving student learning outcomes. Giving precise and easy to understand perceptions, able to deliver and guide students to the material discussed next. Through this perception, students can more easily understand the subject matter so that the material can be well absorbed by students.

The superiority of the mind mapping-assisted two-stay two-stray learning model which is associated with the theory of the characteristics of elementary school students can support the research of the two stay two-strayassisted mind mapping learning model that has been carried out because the two stay two-stray-assisted mind mapping learning model that has been designed has been adjusted to The needs and characteristics of elementary school students so that the application of the two stay two stray learning model assisted by mind mapping can be optimally applied in learning activities. Through this treatment, students become more active, able to work with teams and learn responsibly with the tasks they get in their study groups. Good cooperation produces good results too. Likewise, in this case, cooperation between students is able to foster students' enthusiasm for learning so that learning becomes fun. Students are very enthusiastic about learning and students also find it easier to understand the material being taught. according to the opinion of (Suyanti, 2017), Interaction between students can improve student learning outcomes because students are able to explore their knowledge. If there is no interaction between students, then students become bored quickly and are not enthusiastic in learning, thus making students have difficulty understanding the subject matter given. This will have an impact on student learning outcomes. This research is in line with research conducted by (Juniantari, 2019).

Based on the results of data analysis, the study explained that the two stay two stray cooperative learning model assisted by mind mapping on the social studies learning outcomes of fourth-grade elementary school students in the VIII cluster, Sukasada District, 2017/2018 academic year can improve student learning outcomes. These results are proven based on the results of hypothesis testing with the acquisition of a t-count (3.53)>t -table (2.04). Therefore, the two stay two stray learning model assisted by mind mapping can improve student learning outcomes (Juniantari, 2019). Research conducted by (Batubara, 2019) is also in line with this research. This research states that learning using the TSTS model can improve student learning outcomes in grade IV with the sub-theme of "Diversity of Ethnic and Religious Diversity in My Country" at SD Negeri 7 Langsa. In this study, the results obtained through hypothesis testing obtained t-count (6.955)> t-table (2.0588). Based on the hypothesis test, it can be concluded that the TSTS model can improve student learning outcomes (Batubara et al., 2019). In addition, research that is in line with the results of this study is research conducted by (Karlina, 2017). The results of the data analysis showed that cooperative learning type TSTS assisted with mind maps can improve science learning outcomes through lesson study for fifth-grade students at SDN 2 Paket Agung, Buleleng District, Buleleng Regency. The results obtained from the hypothesis test state $t$-count (3.65)> t table (1.99). This shows that the mind map assisted TSTS learning model can improve student learning outcomes.

Based on the three relevant research results, research using the two stay two stray model assisted by mind mapping has never been applied to the content of science theme 7 "Events in Life", therefore researchers researched the two stay two stray learning model assisted by mind mapping on learning outcomes. IPA theme 7 "Events in Life". The relevant research results indicate that the two stay two stray learning model assisted by mind mapping can improve student learning outcomes. This research implies that the application of the two stay two stray learning model assisted by mind mapping can help the teacher's task in implementing learning because the two stay two stray models has structured steps involving interaction between students so that learning becomes more meaningful. In addition, the use of the mind mapping method makes learning more interesting. Mind mapping can help students' brains to organize, remember, compare, make relationships between materials, and can be designed according to the material needs that must be taught to students, therefore the use of the two stay two stray models assisted by the mind mapping method can improve student learning outcomes

\section{Conclusion}

From the results of the research and discussion presented, it can be concluded that there are significant differences in science learning outcomes between classes that are taught to apply the mind mapping method- 
assisted TSTS learning model and those that do not apply the mind-mapping-assisted TSTS learning model. The two stay two stray models that have structured steps involving interaction between students so that learning becomes more meaningful and more interesting.

\section{References}

Alvin, J. (2015). Analisis Karakteristik Siswa pada Tingkat Sekolah Dasar: Seminar Internasional Pendidikan Islam, 190-205.

Apriliana, S., Sundaygara, C., \& Ayu, H. D. (2019). Pengaruh Model Pembelajaran Guide Inquiry Berbantuan Mind Mapping terhadap Literasi Sains Ditinjau dari Motivasi Belajar Siswa (pp. 145-151).

Arthaningsih, N. K. J. (2018). Pengaruh Model Pembelajaran Kooperatif Tipe Two Stay Two Stray melalui Lesson Study terhadap Hasil Belajar Matematika. Journal of Education Technology, 2(4), 128-136.

Astuti. (2016). Pengaruh Model Pembelajaran Kooperatif Tipe Two Stay Two Stray (Tsts) Terhadap Hasil Belajar Matematika Siswa Kelas Vii Smp Negeri 2 Bangkinang. Jurnal Cendikiawan, 2(1), 11-28.

Batubara, F., Asnawi, A., Riyani, M., \& Sukirno, S. (2019). Pengaruh Model Pembelajaran Two Stay Two Stray terhadap Hasil Belajar pada Sub Tema "Keragaman Suku Bangsa dan Agama di Negeriku" Negeri 7 Langsa. Journal of Basic Education Studies, 2(1), 23-34.

Bilqis, A. I. (2018). Pengaruh Model Pembelajaran Kooperatif Tipe Two Stay Two Stray Terhadap Hasil Belajar Pendidikan Agama Islam Kelas V.

Bujuri, D. A. (2019). Analisis Perkembangan Kognitif Anak Usia Dasar dan Implikasinya dalam Kegiatan Belajar Mengajar. Jurnal Literasi, IX(1), 37-50.

Dewi, A. T. Y. R., \& Negara, I. G. A. O. (2020). Pengaruh Model Pembelajaran ( SAVI ) Berbantuan Multimedia Terhadap Kompetensi Pengetahuan IPA. Mimbar PGSD Undiksha, 8(1), 40-49.

Dimyati, \& Mudjiono. (1999). Belajar dan Pembelajaran.

Ernawati. (2017). Pengaruh Pembelajaran Berbasis Masalah terhadap Hasil Belajar IPA Ditinjau dari Kemampuan Berpikir Kritis. Jurnal Ilmiah Pendidikan IPA, 4(1), 49-54.

Fitrianingrum, W. S. (2018). Pengaruh Model Pembelajaran Two Stay Two Stray terhadap Hasil Belajar IPA pada Siswa Kelas IV. Jurnal Penelitian Pendidikan Guru Sekolah Dasar, 6(6), 945-954.

Gading, I. K., Suja, W., Sudarma, I. K., Divayana, D. G. H., \& Widiana, I. W. (2018). Bahan Ajar Belajar dan Pembelajaran.

Hajar, S., \& Surya, Y. F. (2018). Penerapan Model Pembelajaran Kooperatif Two Stay Two Stray Untuk Meningkatkan Aktivitas Dan Hasil Belajar IPA Siswa Sekolah Dasar. Jurnal Review Pendidikan Dan Pengajaran, 125-138.

Handayani, N. (2018). Efektivitas Model Pembelajaran Two Stay Two Stray ( TSTS ) Ditinjau dari Hasil Belajar Siswa Kelas V SD pada Mata Pelajaran Matematika. International Journal of Elementary Education, 2(1), 15-21.

Handayani, T. (2018). Peningkatan Pemahaman Konsep IPA Menggunakan Model Pembelajaran Inkuiri Terbimbing di SD. Edutainment, 6(2), 130-153.

Hardika, D. (2018). Upaya Meningkatkan Hasil Belajar Siswa Melalui Strategi Two Stay Two Stray pada Mata Pelajaran IPS Materi Koperasi.

Hendra, M. Y., Utaya, S., \& Amirudin, A. (2017). Meningkatkan Motivasi Belajar IPS dengan Model Pembelajaran Two Stay Two Stray Berbantuan Media Power Point.

Hendrawan, K. (2017a). Pengaruh Model Pembelajaran Kooperatif Tipe TSTS terhadap Hasil Belajar Siswa Kelas III SD. Jurnal Mimbar PGSD Undiksha, 5(2).

Hendrawan, K. dkk. (2017b). Pengaruh Model Pembelajaran Kooperatif Tipe Two Stay Two Stray (TSTS) terhadap Hasil Belajar Siswa Kelas III di SD Gugus VIII Kecamatan Buleleng Tahun Pelajaran 2016/2017. Jurnal Mimbar PGSD Universitas Pendidikan Ganesha, 5(2), 1-10. 
Hidayat, H., Mulyani, H., Fatimah, A. S., Sholihat, A., \& Latifah, A. Z. (2020). Penerapan Metode Mind Mapping Untuk Meningkatkan Kreativitas Pada Pembelajaran Pendidikan Kewarganegaraan. Jurnal Pendidikan, $21(1), 38-50$

Huda, M. (2014). Metode-Metode Pengajaran dan Pembelajaran (Cetakan Ke). Pustaka Belajar.

Isjoni. (2016). Cooperative Learning: Efektivitas Pembelajaran Kelompok. Alfabeta.

Juniantari, I. G. A. S. (2019). Pengaruh Model Pembelajaran Kooperatif Two Stay Two Stray Berbantuan Mind Mapping terhadap Hasil Belajar IPS Siswa Kelas IV SD di Gugus VIII Kecamatan Sukasada Tahun Pelajaran 2017/2018. Jurnal Ilmiah Sekolah Dasar, 3(3), 376-386.

Khaulani, F., S, N., \& Irdamurni, I. (2020). Fase Dan Tugas Perkembangan Anak Sekolah Dasar. Jurnal Ilmiah Pendidikan Dasar, 7(1), 51. https://doi.org/10.30659/pendas.7.1.51-59

Kusumayanti, N. K. D. (2013). Pengaruh Strategi REACT Berbantuan Lingkungan sebagai Sumber Belajar terhadap Hasil Belajar IPA Kelas V di Gugus XIII Kecamatan Buleleng. Jurnal Mimbar PGSD Undiksha.

Latifah, A. Z. (2020). Penerapan Metode Mind Mapping untuk Meningkatkan Kreativitas pada Pembelajaran Pendidikan Kewarganegaraan. Jurnal Pendidikan, 21(1).

Muhamad Husni, Z. (2018). Memahami Konsep Pemikiran Mind Map Tony Buzan (1970) Dalam Realitas Kehidupan Belajar Anak. Al-Ibrah|, 3(1).

Pratama, Y., \& Yuniar, E. (2017). Pengaruh Penggunaan Metode Mind Mapping. 1(2), 27-38.

Puspitasari, S. (2019). Upaya Meningkatkan Hasil Belajar IPA dengan Menggunakan Model Pembelajaran Think Pair Share. Jurnal Global Edukasi, 3(1), 55-60.

Rosmalah. (2017). Penerapan Model Pembelajaran Kooperatif Tipe Two Stay Two Stray Untuk Meningatkan Hasil Belajar IPS Siswa Kelas IV SD Negeri 216 Talungeng Kecamatan Barebbo Kabupaten Bone. 120123.

Rusmayanthi, N. L. P. T. (2016). Pengaruh Model Pembelajaran Two Stay Two Stray berbantuan Mind Mapping terhadap Aktivitas dan Hasil Belajar IPA Siswa Kelas V SD di Gugus XIV Kecamatan Buleleng. Jurnal Mimbar PGSD Undiksha, 4(1), 1-9.

Safitri, N. P. L. (2020). Pengaruh Model Pembelajaran Creative Problem Solving Berbantuan Eksperimen Terhadap Kompetensi Pengetahuan IPA Siswa Kelas V. Jurnal Mimbar Ilmu, 25(1), 110-119.

Suja, I. W. (2014). Bahan Ajar Ilmu Alamiah Dasar Berkarakter dan Berkearifan Lokal (Cetakan Ke). Universitas Pendidikan Ganesha.

Suruni. (2018). Peningkatan Prestasi Belajar Bahasa Inggris melalui Metode Mind Mapping di MAN I Gunungkidul. Jurnal Pendidikan Madrasah, Volume, 3(1), 77-87.

Suyanti, N. (2017). Pengaruh Interaksi Sosial Siswa terhadap Hasil Belajar Ekonomi Siswa Kelas X dan XII IPS di SMA Negeri 1 Perhentian Raja Tahun Pelajaran 2013-2014. Jurnal Peka, 4(2), 155-165.

Wote, A. Y. V. (2020). Efektivitas Penggunaan Model Quantum Teaching dalam Meningkatkan Hasil Belajar IPA. Journal of Education Technology, 4(2), 96-102.

Zairmi, U., Fitria, Y., \& Amini, R. (2019). Penggunaan Model Pembelajaran Two Stay Two Stray Dalam Pembelajaran IPA di Sekolah Dasar. Jurnal Basicedu, 3(4), 1031-1037. 